\title{
Population size estimation of the exotic crayfish Procambarus clarkii (Girard) (Crustacea, Decapoda, Cambaridae) in the Alfredo Volpi City Park, São Paulo, Brazil
}

\author{
Humberto Leandro Melo da Silva \& Sérgio Luiz de Siqueira Bueno
}

Rua do Matão, Travessa 14, 101, Cidade Universitária, 05508-900 São Paulo, São Paulo, Brasil.

E-mail: humdoom@ig.com.br; humdoom@terra.com.br; sbueno@ib.usp.br

\begin{abstract}
The size of a well established adult population of the exotic cambarid crayfish Procambarus clarkii (Girard, 1852) from a artificial pond at the Alfredo Volpi City Park, in the city of São Paulo, Brazil, is estimated in four different occasions between 1999 and 2001 by means of a mark-and-recapture technique and Schumacher and Eschmeyer's method for population size determination. Adults were marked by placing small elastic rings at the base of both eyestalks. Population size varied from approximately 269 and 273 adults (the latter corrected by Tanaka's model) in the summer in 2000 and 2001, and between 640 and 468 adults during the winter season of 1999 and 2000, respectively.

KEY WORDS. Mark and recapture technique.

RESUMO. Estimativa do tamanho populacional do lagostim exótico Procambarus clarkii (Girard) (Crustacea, Decapoda, Cambaridae) no Parque Municipal Alfredo Volpi, São Paulo, Brasil. O tamanho de uma população adulta bem estabelecida da espécie exótica de lagostim cambarídeo Procambarus clarkii (Girard, 1852) em um lago artificial no Parque Municipal Alfredo Volpi, localizado na cidade de São Paulo, Brasil, foi estimada em quatro ocasiões distintas entre 1999 e 2001 através de técnica de marcação e recaptura e do método de Schumacher e Eschmeyer para estimativa da população. Os animais adultos foram marcados mediante a colocação de um pequeno anel elástico na base de cada pedúnculo ocular. $O$ tamanho da população adulta variou de aproximadamente 269 e 273 (o último obtido pelo modelo de Tanaka) no verão de 2000 e 2001, e entre 640 e 468 durante o período de inverno de 1999 e 2000 respectivamente.
\end{abstract}

PALAVRAS CHAVE. Técnica de marcação e recaptura.

The North American cambarid crayfish Procambarus clarki (Girard, 1852) has been introduced into many countries in Europe, Asia and Africa for aquaculture purposes (Hоввs et al. 1989, Huner 1989, 1995, Huner \& Lindqvist 1995). There are some reports that these introductions were followed by the establishment of alien $P$. clarkii populations in non-endemic areas and the potencial and actual negative environmental impact thereafter has been regarded as a subject of major ecological concern (Hobbs et al. 1989, Huner 1981). The exotic P. clarkii is reported to cause extensive damages to local benthic fauna and flora (Мколг et al. 1999, Rodrígues-Almaraz \& CAmpos 1994, GutiérRez-Yurrita 1998), to agricultural activities in flooded areas such as rice plantations (Correia \& Ferreira 1995) and to fishing games (Huner 1981). P. clarkii may also carry potential diseases to other crustaceans such as the fungus Saprolegnia parasitica Coker, 1923 (Saprolegniaceae) and Aphanomyces astaci Schikora, 1922 (Saprolegniaceae) (DiéGUEz-URibeondo et al. 1994). Transmission and infection by $A$. astaci has been implicated in the severe reduction in number or even decimation of endemic crayfish populations in Europe (Evans \& EDgERTon 2002).
Apparently, aquaculture ventures might not have been the strongest reason why $P$. clarkii was first introduced in Brazil. Specimens of $P$. clarkii can be easily found and purchased in aquarium shops in the city of São Paulo and that this commercial selling has been carried out for almost 20 years (personal observation). A rapid visit to major aquarium and pet shops in São Paulo today would show that the trading of $P$. clarkii is still a strong business.

In this paper, the adult population size of $P$. clarkii is estimated in four different occasions in one lagoon at the Alfredo Volpi City Park, São Paulo, Brazil, by means of Schumacher and Eschmeyer's method (KREBs 1999). Some considerations on the marking technique in this field study is also presented.

\section{MATERIAL AND METHODS}

The field study was conducted at Alfredo Volpi City Park, located in a residential district in the city of São Paulo, Brazil. The area contains three artificial ponds sequentially connected but placed on different altimetric levels (Fig. 1). The upper most pond ( $23^{\circ} 35^{\prime} 16^{\prime \prime} \mathrm{S}$ and $\left.46^{\circ} 42^{\prime} 09^{\prime \prime} \mathrm{W}\right)$ was chosen for this ex- 

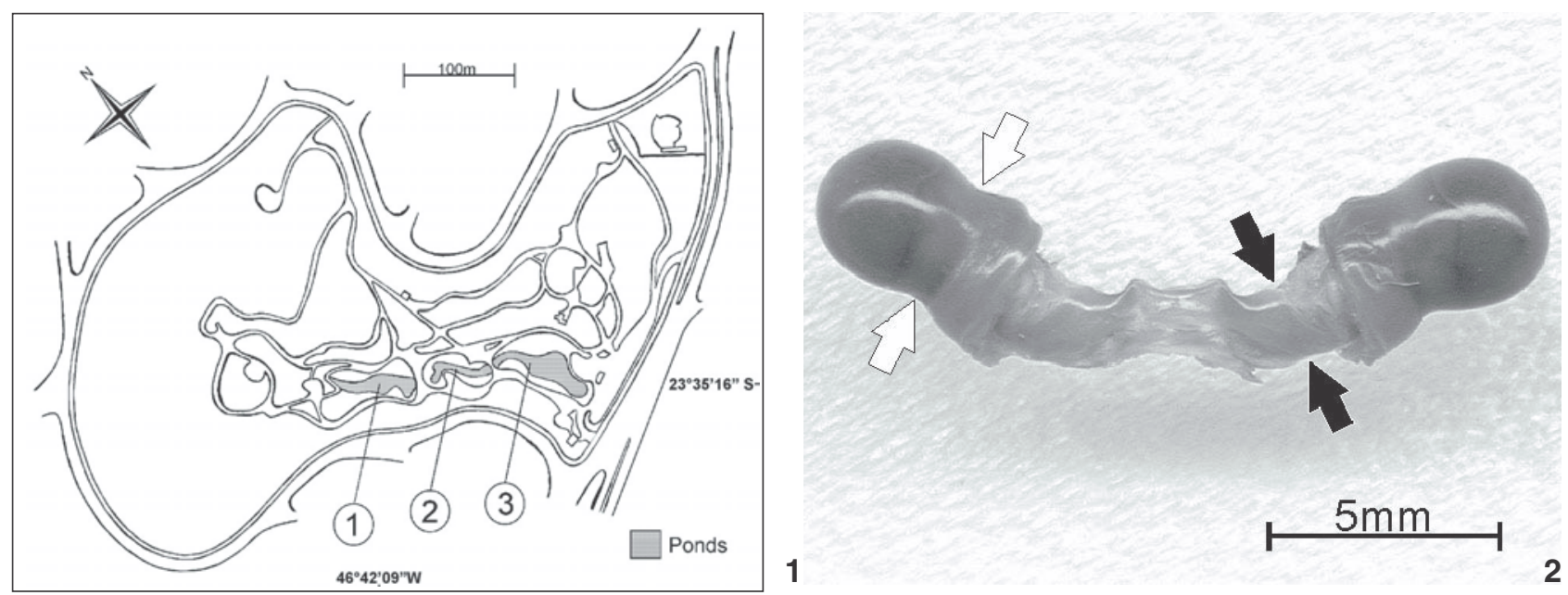

Figures 1-2. (1) Map of Alfredo Volpi City Park showing the ponds highlighted with numbers 1, 2 and 3 (modified from CPHN 1988). The field works were conducted in lake 1, which has a higher altitude than the others. (2) Pair of eye peduncle disecated from P. clarkii, showing its morphology and indicating the correct (black arrow) and the incorrect (white arrow) placement of the elastic ring.

periment and it covers an area of approximately $1,080 \mathrm{~m}^{2}$. The bottom is muddy with some submerged rocks and tree trunks and contains accumulated foliage from surrounding vegetation and trees. At the exit, the excess water gently flows from this pond to the next over the top a concrete wall which is more than one meter deep.

Adult specimens of $P$. clarkii were tagged with small elastic rings (aromatic polyurethane; inner diameter: $1.2 \mathrm{~mm}$ ) commonly employed in orthodontics. One ring was carefully placed at the base of each eye peduncle, which is distinctively narrower than the distal portion which contains the cornea (Fig. 2). To place ring in a fast and neat way, it should first be adjusted around the tip portion and outer side of a ordinary glass pipette. By holding firmly the crayfish, the eyestalk is gently inserted into the hollow tip of the pipette allowing the elastic ring to be easily slid over and transferred to the basal portion of peduncle. The procedure is then repeated on the second eye peduncle. This second elastic ring was employed to increase the chances of recovering and recognising marked animals in case one ring was lost for whatever reason during the field study. However, previous tests conducted in our laboratory showed a $100 \%$ retention of this marking device provided it was positioned at the very base of the eye peduncle. Under this condition, the elastic rings remained tightly in place even after ecdyses (retention of rings after up to three consecutive molts were verified under laboratory conditions). Rings placed at the distal portion of the peduncle near the cornea were frequently lost after ecdyses (Fig. 2).

The present marking technique worked fine for adult specimens only. Juveniles, which posses a characteristic brownish-green body color as compared to the dark red color of the adult forms (BEINGESSER \& COPP 1985), were not marked because the elastic rings did not adjust perfectly in the eye peduncle as well as it did in the adults due to the smaller size of the peduncle in the former. For this reason, only adults were considered for estimating population size.

Animals were captured with the aid of 10-11 traps (Fig. 3 ) randomly distributed in the pond area. Traps were set in the afternoon and retrieved and checked for crayfishes in the next morning. Fresh chicken heart was used as bait inside traps. Presence of marked adult individuals was observed and noted while unmarked ones were then marked. Before their release back to the pond, all adult individuals were sexed, measured (total body length and carapace length) and the occurrence of ovigerous females was noted.

Estimations of the population size of adult $P$. clarkii were performed in four different occasions: two in the Winter (July of 1999 and 2000) and two in the Summer (January of 2000 and 2001). Each of the four estimation studies were composed of 15 samplings which were performed in a short period no longer than three weeks.

Data obtained by the mark-and-recaptured technique were treated according to Schnabel's method for estimating population size, as modified by Schumacher and Eschmeyer (KREBS 1999). The working technique and characteristics of the population studied fit well to the previous assumptions required for the use of the above mentioned methods, such as: 1) the population is of the closed type, which means that population size is assumed to remain the same during the short period of study (variations in number due to migration, mortality or birth are considered negligible); 2) the chance of capture for all individuals is the same; 3 ) marks cannot be lost during each sam-

Revista Brasileira de Zoologia 22 (1): 93-98, março 2005 


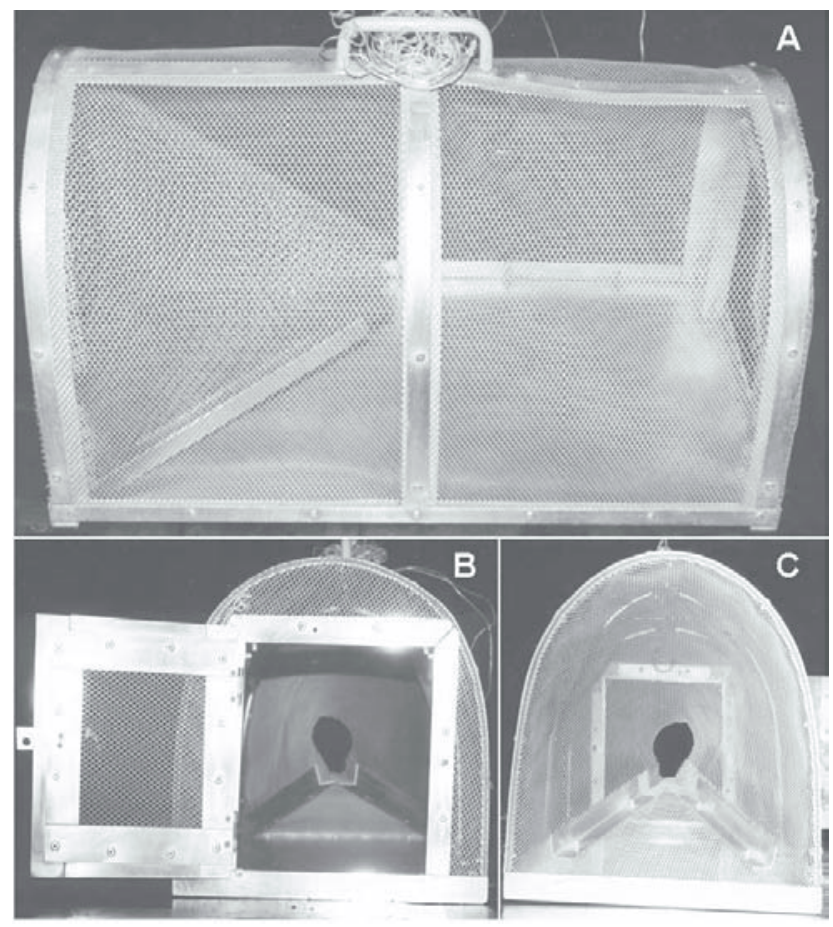

Figure 3. Traps used in the field study. (A) Lateral view of the trap; (B) Frontal view, with door open; (C) Distal view of the traps, showing funnel at the entrance.

pling period and 4) mark must be easily identifiable. Regression plot of data obtained is linear when these premisses are not violated. However, should a curvilinear tendency be noted, as was the case for population estimation in January 2001, this can be corrected by Tanaka's model (Krebs 1999), and a new estimation value is obtained from the $\mathrm{x}$-intersept after data are plotted on double-log graph.

After the field work was completed, some specimens of P. clarkii from the Alfredo Volpi City Park were deposited at the Museu de Zoologia da Universidade de São Paulo (MZUSP) and registered under lots 14501 to 14511 . A few other specimens were also sent to the Instituto Nacional de Pesquisas da Amazônia (INPA) (lot 871), and at the Universidade Federal do Rio Grande do Sul (UFRGS) (lot 03102).

\section{RESULTS}

Table I presents field data and the estimated population size for each period of study. The estimated number of adults by Schumacher \& Eschmeyer's method were higher during the Winter seasons (640 and 468 individuals in July, 1999 and 2000, respectively) while the number of adults estimated was much lower in the Summer (269 animals in January, 2000 and 211 individuals in January, 2001).

Linear regression plots for all four population estimates are presented in figures 4-7. Except for estimation of January 2001, data from the first three estimation fit well on a straight line, indicating that all required assumptions were not violated. However, data from estimation of January 2001 presented a curvilinear tendency (Fig. 7), suggesting that at least one of the premisses was not met. In this case, the result of 211 estimated adults which was previously obtained by Schumacher and Eschmeyer's method was disregarded and a new and corrected estimation of 273 adults was obtained with Tanaka's model (Fig. 8).

Although each of the estimation abundance of adults was performed approximately every 6 months apart, the study of the population structure of this crayfish population were also carried out monthly within the very same 2-years study period. In this time, a noticeable increase in number of dead captured crayfishes inside traps were observed in two different periods (Fig. 9). The first, from September 1999 to January 2000, the accumulated mortality rate reached $11.95 \%$ of all monthly sampled animals (data of the estimation size study performed in January 2000 are included). In the second period, which coincidently occurred in the same months, but an year later, extended from September 2000 to January 2001 and presented a accumulated mortality rate of $3.12 \%$ (data from estimation size study performed in January 2001 are included).

\section{DISCUSSION}

The marking technique employed in this study proved to be quite satisfactory for estimating the population size of adult P. clarkii for two main reasons. Firstly because previous laboratory observations clearly indicated that a $100 \%$ retention of the ring can be expected, even after animals had gone through one or more moltings, provided a properly sized elastic ring is well placed at the base of the peduncle. Problem with defective rings has been minimized in the present study because the elastic rings were of high quality (the same used in orthodontical correction purposes) and presented uniform dimension and shape. Ring did not suffer deterioration during field study and this was probably associated with the positioning of the rings on a highly protected region of the animal (the base of the eyestalk). Additionally, two rings - one in each eyestalk - were used to maximize the chances of recovering marked individuals in case one ring was lost for whatever reason during the field study.

Secondly, each of the four estimation studies were performed for a short period of time and no longer than three weeks. That not only seems to be fairly adequate period for estimating the population size of a closed population of crayfish using Schumacher and Eschmeyer's method but would also guarantee that, in case one or more specimens molted, ecdyses would not likely occur twice for the same adult during that short period of three weeks.

Comparatively, the adult population size estimation showed a higher number of individuals in the Winter than in the Summer. This difference might be associated with two factors:

Revista Brasileira de Zoologia 22 (1): 93-98, março 2005 


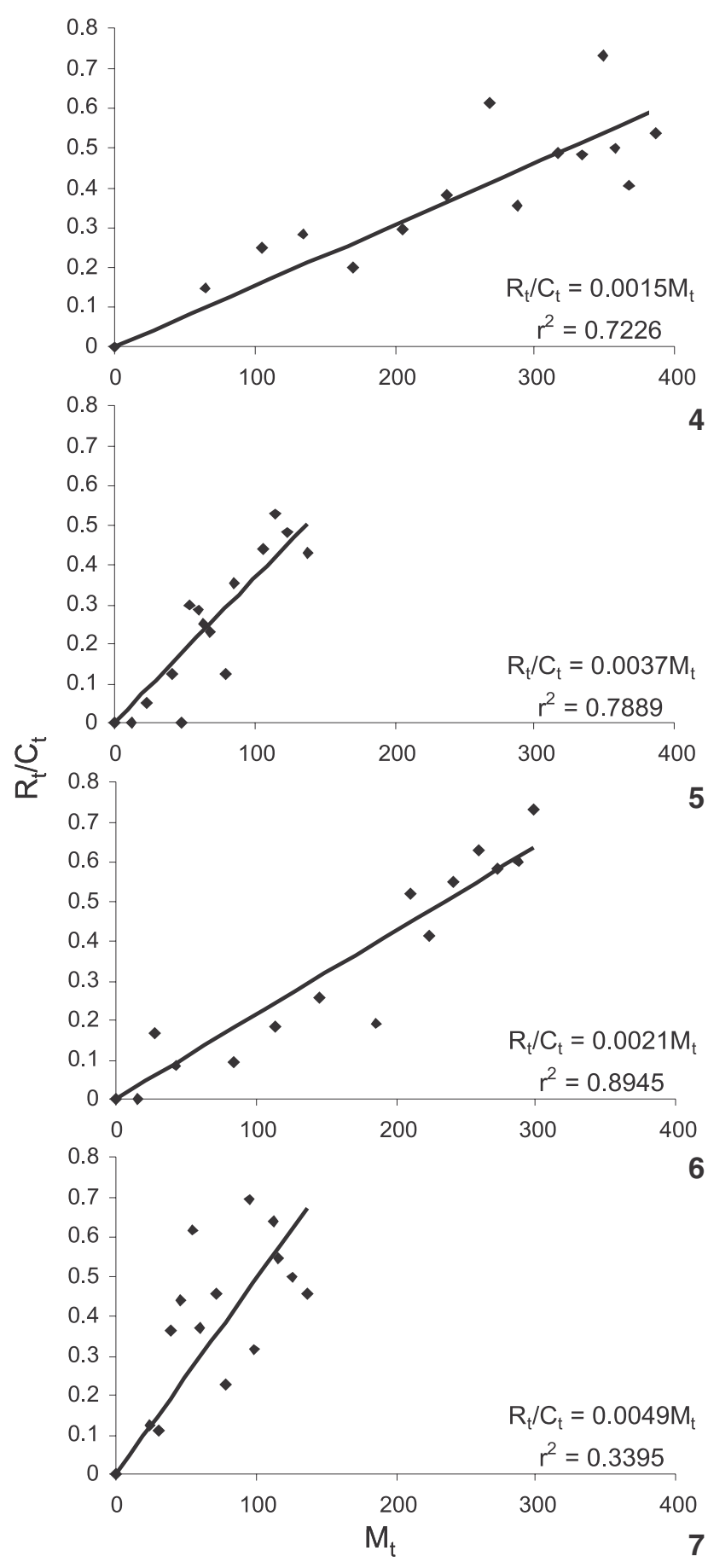

Figures 4-7. Linear regression graphics of the estimates of the adult population of $P$. clarkii; the axes are the proportion of recaptured animals $\left(R_{t} / C_{t}\right)$ and the total number of marked animals in previous sampling $\left(\mathrm{M}_{\mathrm{t}}\right)$; the graphics show tendency line, the line equation and the r-squared for: (4) July 1999; (5) January 2000; (6) July 2000; (7) January 2001.
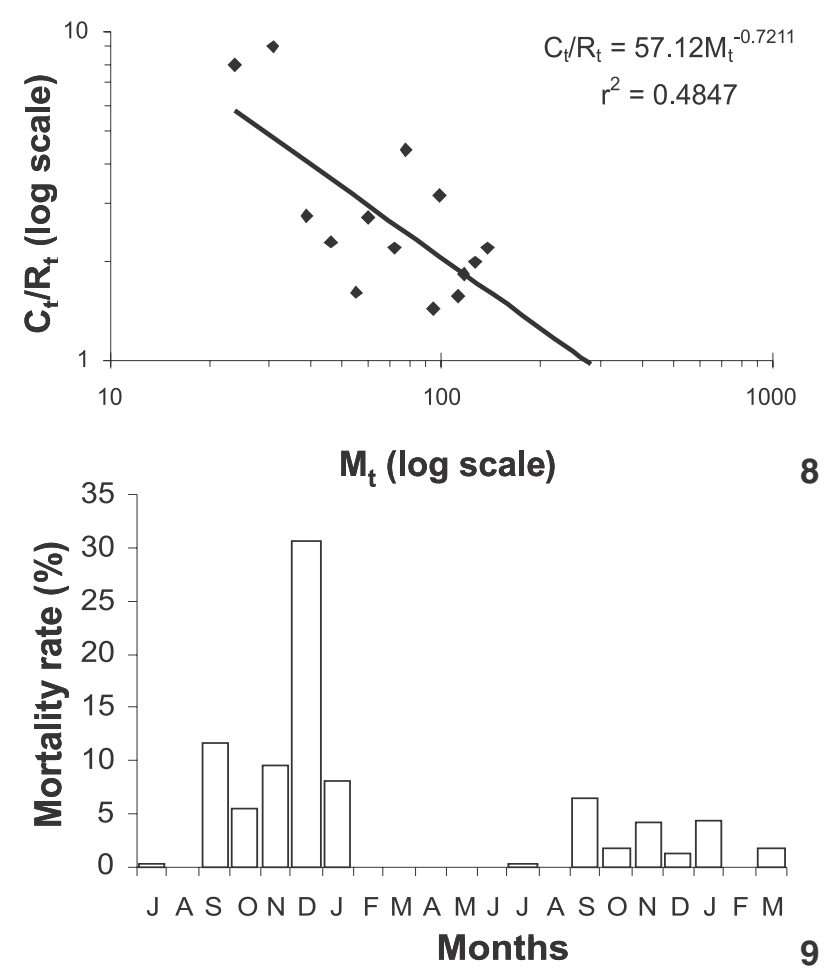

Figures 8-9. (8) Estimation of the adult population of $P$. clarkii as in January 2001, according to Tanaka's model. The intersection of the line with the $X$-axis is the population estimate $(X=273$, for $Y$ =1). (9) Monthly mortality inside the traps between July 1999 and March 2001.

1) The observed decrease might be associated with the changing of habits of adults during the reproductive period. In the Alfredo Volpi City Park lagoon the reproductive period starts in the late Spring and extends till the mid of Summer (Silva, personal observation) during which matured male and female crayfish commonly seek shelter inside constructed burrows, as observed by Correia \& Ferreira (1995) and Fidalgo et al. (2001). This habit would make part of the adult population unavailable for capture by the traps. The reclusion of females in an advanced reproductive state had already been suggested by indirect results from NiqueTte \& D'Abramo (1991) in the USA and CANO \& OCETE (1997) in Spain, where they considered that females were less active when capture efficiency and reproductive stages are compared. In the works of SOMMER (1984) in rice fields in California and of Fidalgo et al. (2001) in a lagoon in Aveiro, Portugal, it was demonstrated that the egg-carrying females are found in the burrows (with a peak at the beggining of summer) and that most of these females were in an advanced reproductive period in summer and beggining of Autumn.

2) The observed accumulated mortality rate between September and January (1999/2000 and 2000/2001), as presented in figure 9 , might have probably contributed to the decrease 
Table I. Results for the 15 consecutive samplings used in the estimation of adult population size of the crayfish P. clarkii in July 1999 , January 2000, July 2000 and January 2001. The table show the variance, standard error and the confidence interval. (Ct) Total number of individuals caught in sample t, (Rt) Number of individuals already marked when caught in sample t, (At) Number of newly marked individuals in sample $t,(\mathrm{Mt})$ number of marked individuals just before sample $t$ is taken.

\begin{tabular}{|c|c|c|c|c|c|c|c|c|c|c|c|c|c|c|c|c|c|c|c|}
\hline Jul. 1999 & $C_{t}$ & $R_{t}$ & $A_{t}$ & $M_{t}$ & Jan. 2000 & $C_{t}$ & $R_{t}$ & $A_{t}$ & $M_{t}$ & Jul. 2000 & $C_{t}$ & $R_{t}$ & $A_{t}$ & $M_{t}$ & Jan. 2001 & $C_{t}$ & $R_{t}$ & $A_{t}$ & $\underline{M_{t}}$ \\
\hline $6 / 30$ & 65 & 0 & 65 & 0 & 11 & 12 & 0 & 12 & 0 & 11 & 16 & 0 & 16 & 0 & 09 & 24 & 0 & 24 & 0 \\
\hline 01 & 47 & 7 & 40 & 65 & $12^{(2)}$ & 12 & 0 & 11 & 12 & 12 & 12 & 0 & 12 & 16 & 10 & 8 & 1 & 7 & 24 \\
\hline 02 & 40 & 10 & 30 & 105 & 13 & 19 & 1 & 18 & 23 & 13 & 18 & 3 & 15 & 28 & 11 & 9 & 1 & 8 & 31 \\
\hline 06 & 49 & 14 & 35 & 135 & 14 & 8 & 1 & 7 & 41 & 14 & 46 & 4 & 42 & 43 & 12 & 11 & 4 & 7 & 39 \\
\hline 07 & 45 & 9 & 36 & 170 & $15^{(2)}$ & 7 & 0 & 6 & 48 & 15 & 32 & 3 & 29 & 85 & 13 & 16 & 7 & 9 & 46 \\
\hline 08 & 44 & 13 & 31 & 206 & $18^{(2)}$ & 10 & 3 & 6 & 54 & 18 & 38 & 7 & 31 & 114 & 16 & 13 & 8 & 5 & 55 \\
\hline 09 & 50 & 19 & 31 & 237 & $19^{(1)}$ & 7 & 2 & 4 & 60 & 19 & 55 & 14 & 41 & 145 & 17 & 19 & 7 & 12 & 60 \\
\hline 13 & 52 & 32 & 20 & 268 & 20 & 8 & 2 & 6 & 64 & 20 & 31 & 6 & 25 & 186 & 18 & 11 & 5 & 6 & 72 \\
\hline 14 & 45 & 16 & 29 & 288 & 21 & 13 & 3 & 10 & 69 & 21 & 27 & 14 & 13 & 211 & 19 & 22 & 5 & 17 & 78 \\
\hline 15 & 33 & 16 & 17 & 317 & 22 & 8 & 1 & 7 & 79 & 22 & 29 & 12 & 17 & 224 & 20 & 13 & 9 & 4 & 95 \\
\hline 16 & 29 & 14 & 15 & 334 & 25 & 31 & 11 & 20 & 86 & 25 & 40 & 22 & 18 & 241 & 23 & 19 & 6 & 13 & 99 \\
\hline 20 & 30 & 22 & 8 & 349 & 26 & 16 & 7 & 9 & 106 & 26 & 38 & 24 & 14 & 259 & 24 & 11 & 7 & & 112 \\
\hline 21 & 20 & 10 & 10 & 357 & 27 & 19 & 10 & 9 & 115 & $27^{(3)}$ & 36 & 21 & 14 & 273 & 25 & 22 & 12 & 10 & 116 \\
\hline $22^{(1)}$ & 37 & 15 & 21 & 367 & 28 & 27 & 13 & 14 & 124 & 28 & 30 & 18 & 12 & 287 & 26 & 22 & 11 & & 126 \\
\hline 23 & 26 & 14 & - & 387 & 29 & 28 & 12 & - & 138 & 29 & 41 & 30 & - & 299 & 27 & 11 & 5 & - & 137 \\
\hline \multicolumn{5}{|c|}{$\begin{array}{l}\text { Var } \approx 0.43 ; \text { S.E. } \approx 0.0001 \\
\text { Conf. intervals }=556 \text { to } 753\end{array}$} & \multicolumn{5}{|c|}{$\begin{array}{l}\operatorname{Var} \approx 0.08 ; \text { S.E. } \approx 0.0002 \\
\text { Conf. intervals }=241 \text { to } 310\end{array}$} & \multicolumn{5}{|c|}{$\begin{array}{l}\text { Var } \approx 0.23 ; \text { S.E. } \approx 0.0001 \\
\text { Conf. intervals }=422 \text { to } 525\end{array}$} & \multicolumn{5}{|c|}{$\begin{array}{l}\text { Var } \approx 0.42 ; \text { S.E. } \approx 0.0005 \\
\text { Conf. intervals }=172 \text { to } 274\end{array}$} \\
\hline
\end{tabular}

(1) Two adults (one of them tagged) were found dead, resulting in a lower Mt value in the following sampling; (2) One dead and unmarked adult specimen; (3) One unmarked ovigerous female which was taken to the laboratory.

in the population size estimated observed in the two consecutive Summers. Since no mortalities were observed in the previous periods of July and August of 1999 and February to August of 2000, it is here assumed that the last period represented a recovery phase of the population size. The higher accumulated mortality rate of September of 1999 to January of 2000, might be associated with contamination of the water of the lagoon by domestic sewage from the sorrounding neighbourhood in that period, as reported to us by employees of the Alfredo Volpi City Park. Indeed, during that period we have observed a noticeable change in the color of water, turning more "black", and a distinct fetid odour emanating from the lagoon.

Coincidently, another noticeable accumulated mortality rate was observed in the following period from September of 2000 to January of 2001 . In this case, however, the accumulated mortality rate was much lower than that observed in the previous year, but the loss of adult individual still had some negative effect on the number of surviving adults as verified in the last estimation conducted in January of 2001.

\section{ACKNOWLEDGEMENTS}

We are greatfull to the Programa de Pós-Graduação (Zoologia) of the Instituto de Biociências da Universidade de São Paulo and Departamento de Parques e Áreas Verdes do Município de São Paulo (DEPAVE) for the logistics support during the study. We also thank Humberto Y. Yamaguti e Fernanda V. Capociama for their valuable assistance in field work. Felipe F. Curccio and José S.L. Patané for their criticism on the manuscript. The senior author (HLMS) was supported by grant of Fundação de Amparo à Pesquisa do Estado de São Paulo (FAPESP, \# 99/07159-6).

\section{REFERENCES}

Beingesser, K.R. \& N.H. Copp. 1985. Differential diurnal distribution of Procambarus clarkii (Girard) juveniles and adults and possible adaptive value of color differences between them (Decapoda, Astacidea). Crustaceana, Leiden, 49: 164-172.

Cano, E. \& M.E. Ocete. 1997. Population biology of red swamp crayfish, Procambarus clarkii (Girard, 1852) in the Guadalquivir River Marshes, Spain. Crustaceana, Leiden, 70: 553561.

Correia, A.M. \& Ó. Ferreira. 1995. Burrowing behavior of the introduced red swamp crayfish Procambarus clarkii (Decapoda: Cambaridae) in Portugal. Journal of Crustacean Biology, Lawrence, 15 (2): 248-257.

Cphn. 1988. Parque Morumbi, p. 8-9. In: Centro de Pesquisa de História Natural (Ed.). Conheça o Verde. São Paulo, Ed. Oriento, XIII.

Diéguez-Uribeondo, J.; L. Cerenius \& K. Söderhäll. 1994. Saprolegnia parasitica and its virulence on three different species of

Revista Brasileira de Zoologia 22 (1): 93-98, março 2005 
freshwater crayfish. Aquaculture, Amsterdam, 120: 219-228.

Evans, L.H. \& B.F. Edgerton. 2002. Pathogens, parasites and commensals, p. 377-438. In: D.M. Holdich. (Ed.). Biology of Freshwater Crayfish. Oxford, Ed. Blackwell Science, $\mathrm{X}+654 \mathrm{p}$.

Fidalgo, M.L.; A.P. Carvalho \& P. Santos. 2001. Population dynamics of the red swamp crayfish, Procambarus clarkii (Girard, 1852) from the Aveiro region, Portugal (Decapoda, Cambaridae). Crustaceana, Leiden, 74 (4): 369-375.

GutiéRREz-Yurrita, P.J. 1998. El papel ecológico del cangrejo rojo (Procambarus clarkii) en los ecosistemas acuáticos del Parque Nacional Doñana: una perspectiva ecofisiológica y bioenergética. Crayfish News, Lafayette, 20 (1/2): 10-12.

Hobis III, H.H.; J.P. Jass \& J.V. HunER. 1989. A review of global crayfish introductions with particular emphasis on two North American species (Decapoda, Cambaridae). Crustaceana, Leiden, 56 (3): 299-316.

HunER, J.V. 1981. Information about the biology and culture of the red crawfish, Procambarus clarkii (Girard, 1852) (Decapoda, Cambaridae) for fisheries managers in Latin America. Anales del Instituto de Ciencias del Mar y Limnologia, Universidad Nacional Autónoma de México, México, 8 (1): 43-50.

Huner, J.V. 1989. Overview of international and domestic freshwater crawfish production. Journal of Shellfish Research, Maine 8 (1): 259-265.

Received in 28.V.2004; accepted in 18.1.2005.
HUNER, J.V. 1995. An overview of the status of freshwater crawfish culture. Journal of Shellfish Research, Maine, 14 (2): 539-543.

Huner, J.V. \& O.V. LindQvist. 1995. Physiological adaptations of freshwater crayfishes that permit successful aquacultural enterprises. American Zoologist, Lawrence, 35: 12-19.

Krebs, C.J. 1999. Ecological Methodology. Menlo Park, Benjamin/Cummings, $2^{\text {nd }}$ ed., XV+620p.

Mkoji, G.M.; B.V. Hofkin; A.M. Kuris; A. Stewart-Oaten; B.N. Mungai; J.H. Kihara; F. Mungai; J. Yundu; J. Mbui; J.R. Rashid; C.H. Kariuki; J.H. OUMa; D.K. KoeCh \& E.S. LOKER. 1999. Impact of the crayfish Procambarus clarkii on Schistosoma haematobium transmission in Kenya. American Journal of Tropical Medicine and Hygiene, Baltimore, 61 (5): 751-759.

Niquette, D.J. \& L.R. D'ABramo. 1991. Population dinamics of red swamp crawfish, Procambarus clarkii (Girard, 1852) and white river crawfish, $P$. acutus acutus (Girard, 1852), cultured in earthen ponds. Journal of Shellfish Research, Maine, 10 (1): 179-186.

Rodríguez-Almaraz, G.A. \& E. Campos. 1994. Distribution and status of the crayfishes (Cambaridae) of Nuevo León, México. Journal of Crustacean Biology, Lawrence, 14 (4): 729 735.

Sommer, T.R. 1984. The biological response of the crayfish Procambarus clarkii to transplantation into California ricefields. Aquaculture, Amsterdam, 41: 373-384. 